\title{
Research on Metallurgical Project Design and Practices: Case Study CCTEC Co. Ltd.
}

\author{
Kamonja Giron ${ }^{*}$, Liang Yan ${ }^{1}$, Yangping Zhao², Muhammad Tayyab Sohail ${ }^{3}$ \\ ${ }^{1}$ School of Economic and Management, China University of Geosciences, Wuhan, China \\ ${ }^{2}$ International Education College, China University of Geosciences, Wuhan, China \\ ${ }^{3}$ School of Public Administration, China University of Geosciences, Wuhan, China \\ Email: gkamonja2001@yahoo.fr, tayyabsohail@yahoo.com
}

Received 20 May 2014; revised 10 June 2014; accepted 3 July 2014

Copyright (C) 2014 by authors and Scientific Research Publishing Inc.

This work is licensed under the Creative Commons Attribution International License (CC BY).

http://creativecommons.org/licenses/by/4.0/

c) (i) Open Access

\begin{abstract}
This paper discerns the socio-economic interests and environmental impacts generated by the projects of an industrial nature. Research has highlighted the traditional approach adoption that neglects the impact assessment of which environmental issues are causing in-depth imbalance between economic growth and environmental disaster threatening human life. The sustainable development principle requires the equitable distribution of the newly created wealth owing to economic growth in social and environmental fields. Hence, a new approach in accordance with the requirements of sustainable development should be recommended from the projects' design until their terms. This paper discusses the major challenges in the context of reorient to construction projects both in a conception stage than in the execution progress according to the sustainable development principle. An approach to this case study is the research method advocated. Traceability analysis and especially the followed of products sold by CCTEC Co. Ltd. have enabled to bring out on the one hand the four projects induced by products CCTEC Co. Ltd.: residential, public sector, industry and trade the other hand to measure the performance attributed by these projects. Research results show that economic performance is largely award winning without much concern to social and environmental performance. This situation suggests the revision of product design and production traceability in accordance with the sustainability of the project.
\end{abstract}

\section{Keywords}

Project Design, Management Practice, Sustainable Development

\section{Introduction}

Metallurgical Design Project concerns interactions, integrations and significant relationships in socio-economic

${ }^{*}$ Corresponding author.

How to cite this paper: Giron, K., Yan, L., Zhao, Y.P. and Sohail, M.T. (2014) Research on Metallurgical Project Design and Practices: Case Study CCTEC Co. Ltd. American Journal of Industrial and Business Management, 4, 345-354. 
systems [1]. By doing reference to the metallurgical business, it contributes more through supplying the capital goods and materials needed for construction [2]. Sustainable development requires the basic infrastructure implementation which most materials are at the metals origin. The increase in demand for goods derived from metals at market directly causes the existence of the additional demand [3]. Faced with an imbalance between supply and demand, the firm's behavior is often to revise the prices upwards. The increase in production volume by competitors, enable to balance supply and demand in the market [2] [3]. Additional production has enabled to satisfy the additional demand; thus, the market price is the equilibrium price. Indeed, all stakeholders in the market draw from profits. This is a schema which the result leads of win-win outcome. The company withdrawn more profit when there is an imbalance between supply and demand; the price subsequently soared [4]. On the consumer side, they receive gains occasioned by the difference between the price at which the consumer is willing to buy and the equilibrium price [4] [5]. Other studies address the importance of Corporate Social Responsibility (CSR) especially in the process of promoting sustainable development [6]. Indeed, CSR is rather focused on ethical behavior related to three components: environment, society and economy [7]. When the heavy or processing companies are going to proceed in production, they often set up a CSR policy before all the operations, in order to deal with negative externalities caused by the production. CSR is known as a means enabling to repair the damage from the exploitation and/or production towards the environment and increase in value the social dimension that is often overlooked [6] [7].

Promoting metallurgical project encourages sustainable construction activities. Products quality improvement is at the origin of design research in the production units [8]. This means that the products quality determination destined for selling is the result of the design study undertaken. Upstream research considers products design and this design that has been designed beforehand will be defined by the quality of materials or capital goods after having followed the production process [9]. A product differs from another by its quality. This one is considered as an indicator choice for the client. Before embarking on the purchase, the customer first examines the product quality which he intends to buy. This amounts to saying that the buyers' choice focus on the quality preference and it will then be lead to take the decision to purchase [8]. Sales improvement of the company is resulting from increasing units' number of products sold at market. Given that the cut-throat competition, it is difficult to increase the volume of products sold from one year to another. Indeed, in order to reach this challenges, the company must remain competitive in front its competitors [10]. Products quality improvement is an effective tool to ensure the pace of competition in the international market [8] [10]. Turnover improvement implies that the company has increased profits. This situation gives rise to a positive externality in the context of the sustainable development process. Promoting sustainable construction practice is the result of increase in new values created after increasing profit. The total of added value determines the Gross Domestic Product (GDP) which ends in economic performance [11]. The latter provides the necessary means within the framework to pursue a balance in the social and environmental fields. Various methods likely to reduce the pollution generated by the factory production have been made; the prevention of waste production constitutes a way that involves less damage to the environment [12].

Always in order to reduce the damage risk caused by the economic growth to the environment level, the current trend of large company producing capital goods and equipment materials converges towards recycling waste in the production of materials and equipment [11] [12]. Waste reusing processed into raw materials and then used again in the component of the production factors combination is very beneficial not only to society but also very profitable to the company [13]. Metallurgical project design is a vector for innovation in all sectors including sustainable construction. One cannot imagine the innovation without to pass by the design study. Technical progress and technological development enable to promote an upward evolution within the framework of the products design [14]. The companies offer materials and equipment goods with high technology responding innovation policy required by the sustainable development without compromising the environment. However, it is clear that the concept of sustainability is oriented generally in the construction sector; the sustainability research can cause a conflict between environmental benefits in long term and operational economic objectives in short-term [15]. The sustainable development philosophy consists generally to meet the basic needs of the population and to respond the aspirations of the well-being of everyone without compromising nevertheless to expand the possibility to guarantee a better life for future generations [16]. Promote future generations requires the control of the tripartite balance, balance of environmental protection, economic development and social development. The three components that make up sustainable development: environmental protection, economic de- 
velopment and social development necessitate the money to engage investment projects in these three respective fields [15] [16]. In this sense, some studies have suggested that the adoption of sustainability principles in the process of implementation of construction projects can contribute to profit making [17]. It is particularly very important to adopt the principle of conducting a project design study. The purpose of this study is to design directly consumable products that exactly meet to the trend of customers at market level [18]. On the other side, it also enables to assess the likely estimate on the quality of metallurgical products which the markets have needed but also especially to calculate approximately the damage cost generated during production, properly speaking. Indeed, strategies such as CSR are proposed to implement sustainable practices [19]. Therefore, design studies projects are often conducted in advance for having a better understanding on the one part and then to facilitate reaching the expected objectives: acquiring durability in the process of sustainable development including the implementation of construction project is a major part [20]. Project design implementation is often preceded by a feasibility study. The project success will be conditioned by a perfect conclusion of design and construction. However, it is difficult to pretend to land at a good realization when the feasibility study which was undertaken is not effective. Traditionally, the project feasibility study is focused on financial issues. It is a question of calculating the output investment rate, of estimating the imbalance between supply and demand quantity available in order to deduct the additional demand quantity, and finally of assessing the competition weight in the traditional market and the integration cost in the new markets [19]. It is clear that the feasibility study is a pet hate for the designing success indeed of the developing project [20]. It indicates the purely technical aspects which understanding is complicated by a simple lecture. Nevertheless, it is the most important stage; having committed mistakes at this stage might be permanently handicapping the project's performance even fatally. A feasibility study upstream considered adequate and effective is just a set of financial projections that may have repercussions downstream on the market-driven strategic plan and a roadmap for all subsequent decisions.

Given that sustainable development is the result of the improvement of sustainable economic growth, indeed, the promotion of sustainability has become increasingly important in various sectors of activity. One is particularly in levels of production units operating within companies. As most production at factories give off toxic waste that will harm the atmosphere, rivers, sea etc. finally, human life is threatened [21]. Ultimately, the aim of promoting the social and economic issues has become the vector potential threatening environmental issues in the current practice of the project construction [22]. This fact leads us directly to introduce the assessment of the environmental impact in the study design project whose objective is to recommend the repair of damage caused during production [23]. Undoubtedly, economic agents especially those working in heavy industries and processing industries such as the case of CCTEC Co. Ltd. are polluters, and it has widely reported and heavily criticized by environmentalists [21] [24]. The tasks division is clear and sharp. The government sets the environmental protection policy and ensures the implementation of the related activities with Non-Governmental Organizations concerned. Companies are a part of the mechanism propulsion economic development. The government encourages them to increase investment so that there is an annual increase of newly created wealth [25]. Given that the primary objective of the company is to maximize profit, thus they have the tradition of focusing on controlling fixed costs such as salaries, production costs and the production cycle duration along with the quality of products [26]. Despite certain studies, propose solutions to minimize distortion of the environment, environmental and social performances remain still precarious in China [16] [21] [23]. The increase in the allocation for CSR is difficult to imagine, therefore it is still limited. This limitation is the origin of industry culture centered on profit where cost, quality and schedule were key factors to ensure super profit [27]. Actually, China is the country of destination of American and European industrialists to set up annex industries. The industry transfer is doing so in order to making profit owing to cheapest labor in the country [28]. It also reduces the risk of environmental degradation in the United States and Europe in order to escape the climatic problem generated by climate change. Indeed, the industry activities in China have resulted in economic boom; the economy experienced a marked improvement after the increase in job creation [25]. This one contributes in improving endogenous income redistribution; each household could increase its consumption level through his salary [29]. A significant improvement was also noted at the public treasury due to an increase in tax revenue and especially the increase in foreign currencies reserves at the central bank due to the overwhelming influence of international trade [30]. This ensures the stability of the Chinese money Yuan or appreciation of its value [31] [32]. The preponderance of export is the origin the development of Foreign Domestic Investment (FDI) [28]. However, secondary effects were registered during industrial activities such as environmental pollution, resource waste, secu- 
rity issues and the public interest [21] [23] [24]. These problems mentioned have major incidence in the context of implementing the principles of sustainable development in China [16] [21]. In fact, there is a contrast which manifests itself between better environmental protection and current practice of the investment project. Therefore, this paper aims to examine the current practice of conducting research on the design of the project by taking the case of CCTEC Co. Ltd.

\section{Research Methodology}

To provide heated discussions and in-depth understanding of this research, a case study approach has been chosen to illustrate the study. From September to December 2013 period of my internship in CCTEC Co. Ltd, I had an opportunity to conduct an inventory of sales register during four commercial years 2008 to 2011. Indeed, 158 machinery units (such as Billet CCM, Bloom \& Round CCM and Slab CCM) were purchased by Iron \& Steel and Equipment \& Engineering companies, which selling classification is as follows: 52 units in residential projects (PI), 50 units in the public sector projects (PII), 37 units in the industrial projects (PIII) and 19 units in the commercial projects (PIV). Both type of companies whose economic function is to provide construction materials and equipment goods, stimulate a snowball effect on various projects enumerated above. The interview with Financial Manager enables to obtain first-hand information on the practice of conducting study regarding the impact on socio-economic and environmental issues. The examination of these cases in Hubei and Guangdong provinces leads to understanding on what and how CCTEC Co. Ltd. was attributed through Iron \& Steel and Equipment \& Engineering companies within the current framework of promoting sustainable development. Therefore, the analysis cannot be given whether these attributes are correct or sufficient for the sustainable development principle implementation. Challenges can reveal for the practical implementing of sustainable construction in China. The protection of local processing companies should be strengthened in order to accelerate the mutation process towards the sustainable development principle while highlighting areas that have not been given attention. Measures should be taken to improve the weak points.

\section{Results and Analysis}

The production of capital goods by metallurgical company contributes largely to the achievement of various projects. The contribution degree can be measured by examining the factors or attributes provided by these capital goods supplied in relation to the expected result. These attributes can be viewed in three main areas: namely economic performance attributes, social performance attributes and environmental performance attributes. This paper was shown the attributes importance in each domain with the reference to the Chinese context.

\subsection{Economic Performance Attributes}

Economic performance attributes (EPAs) are used for assessing the economic performance generated by investment activities. These attributes are served within the framework to estimate market availability, project financing and economic benefits provided by the implementation of the investment project [1] [5] [15]. By examining the commercial documents (tender documents, call for manifestation interest) and survey reports, a list of EPAs were taken into account shown in Table 1.

The application of these attributes in the surveyed projects varies significantly. Table 2 provides statistical summary on the application of various attributes (EPAs) for assessing economic performance in metallurgical project study of EPAs in the four types of surveyed projects.

Table 2 indicates that $94 \%$ of surveyed residential projects take into account EPA "market forecast". However, this rise $\mathrm{EPA}_{4}$ "market forecast" cannot guarantee successful investments, since there are only half of the projects considered $\mathrm{EPA}_{14}$ "finance risk assessment, $\mathrm{EPA}_{15}$ " return on investment", $\mathrm{EPA}_{16}$ "net present value". It is found that a good attention should determine the market reality on the future conducting of residential projects realization. The minimization of risk assessment is causing the decline in percentage $\mathrm{EPA}_{15}$ and $\mathrm{EPA}_{16}$.

Concerning the projects in the public sector areas, the preliminary study presents $98 \%$ exactly meeting market expectations, $\mathrm{EPA}_{3}$ "demand and supply analysis" however; there are only $3 \%$ of the surveyed projects implemented $\mathrm{EPA}_{6}$ "market competition". It is indispensable to review the market need for potential projects in the public sector. In China, the government is the prime contractor for all public works. This leads to unfair competition towards the private sector, from where poor consideration is given to market competition. 
Table 1. Attributes in metallurgical project.

\begin{tabular}{|c|c|}
\hline \multicolumn{2}{|l|}{ Economic performance attributes } \\
\hline EPA $_{1}$ : Governmental strategic development policy & $\mathrm{EPA}_{10}$ : Financing channels \\
\hline $\mathrm{EPA}_{2}$ : Tax policy & $\mathrm{EPA}_{11}$ : Investment plan \\
\hline $\mathrm{EPA}_{3}$ : Demand and supply analysis & $\mathrm{EPA}_{12}$ : Life cycle cost \\
\hline $\mathrm{EPA}_{4}$ : Market forecast & $\mathrm{EPA}_{13}$ : Life cycle profit \\
\hline $\mathrm{EPA}_{5}$ : Project function and size & $\mathrm{EPA}_{14}$ : Finance risk assessment \\
\hline $\mathrm{EPA}_{6}$ : Market competition & $\mathrm{EPA}_{15}:$ Return on investment (ROI) \\
\hline $\mathrm{EPA}_{7}$ : Location advantage & $\mathrm{EPA}_{16}$ : Net present value (NPV) \\
\hline $\mathrm{EPA}_{8}$ : Technology advantage & $\mathrm{EPA}_{17}$ : Pay-back period \\
\hline EPA9: Budget estimate & $\mathrm{EPA}_{18}$ : Internal rate of return (IRR) \\
\hline \multicolumn{2}{|l|}{ Social performance attribute } \\
\hline $\mathrm{SPA}_{1}$ : Influence to the local social development & $\mathrm{SPA}_{6}$ : Safety standards \\
\hline $\mathrm{SPA}_{2}$ : Provision capacity of employment & $\mathrm{SPA}_{7}$ : Improvement to the public health \\
\hline $\mathrm{SPA}_{3}$ : Provision capacity of public services & $\mathrm{SPA}_{8}$ : Increase in consumption level \\
\hline $\mathrm{SPA}_{4}$ : Provision capacity of public infrastructure facilities & $\mathrm{SPA}_{9}$ : Improvement to standards of living \\
\hline \multicolumn{2}{|l|}{$\mathrm{SPA}_{5}$ : Improvement to wellbeing } \\
\hline \multicolumn{2}{|l|}{ Environmental performance attributes } \\
\hline EnPA $_{1}$ : Eco-environmental sensitivity of the project location & $\mathrm{EnPA}_{4}$ : Noise assessment \\
\hline EnPA $_{2}$ : Air impacts & EnPA $_{5}$ : Waste assessment \\
\hline \multirow[t]{2}{*}{$\mathrm{EnPA}_{3}$ : Water impacts } & EnPA $_{6}$ : Environmental friendly design \\
\hline & EnPA $_{7}$ : Energy consumption performance \\
\hline
\end{tabular}

About the industrial projects, around 97\% of surveyed industrial project implemented EPA9 "budget estimate”, however there exist only approximately less than $50 \%$ of the surveyed projects implemented $\mathrm{EPA}_{6}$ "market competition" and $\mathrm{EPA}_{14}$ "finance risk assessment". It appears that the budget availability is a condition sine qua non to start the industrial projects development. It is noted elsewhere little attention is manifested to competition services and risk assessment. This phenomenon is explained by an increase in the marginal substitution rate whose the price is very competitive (Table 1 ).

In examining commercial projects, approximately $95 \%$ of surveyed projects implemented $\mathrm{EPA}_{5}$ "project function and size" it has only $21 \%$ of surveyed project implemented $\mathrm{EPA}_{6}$ "market competition" in the documents found. It is judicious to clarify that making decision on the project development is a function of the evaluation of function and size of said commercial project. Furthermore, it is important to note that little attention is given to the competition animation concerning the development of commercial project.

\subsection{Social Performance Attributes}

Social development is part of indicators that measure social performance generated by the exponential pace of economic growth which the origin of this speed is nothing but the resultant of increase in the investment rate [11] [12] [15]. By focusing on the examination surveyed feasibility studies reports, a list of SPAs was enumerated in Table 1. The application of these attributes in the four types of projects studied varies randomly. Table 2 provides a statistical summary concerning the percentage change of social performance. It is noticed that the private sector has not intervened significantly to social performance. It focuses on the business which primary objective is to realize the maximum profit. Indeed, although the residential project has influences on local development but the result remains precarious, $\mathrm{SPA}_{2}$ "provision capacity of employment", $\mathrm{EPA}_{3}$ "provision capacity of public services" and $\mathrm{SPA}_{4}$ "capacity provision of public infrastructure facilities" have no effect on $\mathrm{SPA}_{7}$ "Improvement to the public health", $\mathrm{SPA}_{8}$ "Increase in consumption level” and SPA “Improvement to standard of living". It is the same for the industrial project. Admittedly $\mathrm{SPA}_{2}$ "provision capacity of employment" might influence $\mathrm{SPA}_{8}$ "increase in consumption level" and $\mathrm{SPA}_{9}$ "improvement to standard of living", but it should not forget that 
Table 2. Demand of attributes in metallurgical PI-residential; PII-public sector; PIII-industrial; PIV-commercial; R-demand rate.

\begin{tabular}{|c|c|c|c|c|c|c|c|c|}
\hline Attributes & $\begin{array}{c}\text { PI } \\
\text { (max: } 52)\end{array}$ & RI (\%) & $\begin{array}{c}\text { PII } \\
\text { (max: } 50)\end{array}$ & RII (\%) & $\begin{array}{c}\text { PIII } \\
\text { (max: 37) }\end{array}$ & RIII (\%) & $\begin{array}{c}\text { PIV } \\
\text { (max: 19) }\end{array}$ & RIV (\%) \\
\hline $\begin{array}{l}\text { EPA1: Governmental strategic } \\
\text { development policy }\end{array}$ & 43 & 82 & 32 & 64 & 31 & 84 & 8 & 42 \\
\hline EPA2: Tax policy & 46 & 88 & 34 & 68 & 18 & 49 & 14 & 73 \\
\hline EPA3: Demand and supply analysis & 47 & 90 & 49 & 98 & 34 & 92 & 11 & 58 \\
\hline EPA4: Market forecast & 49 & 54 & 54 & 54 & 30 & 81 & 16 & 82 \\
\hline EPA5: Project function and size & 48 & 92 & 42 & 84 & 31 & 83 & 18 & 95 \\
\hline EPA6: Market competition & 43 & 82 & 04 & 08 & 18 & 49 & 04 & 21 \\
\hline EPA7: Location advantage & 36 & 69 & 33 & 66 & 32 & 86 & 14 & 73 \\
\hline EPA8: Technology advantage & 32 & 61 & 32 & 64 & 34 & 91 & 12 & 63 \\
\hline EPA9: Budget estimate & 32 & 61 & 45 & 90 & 36 & 97 & 14 & 73 \\
\hline EPA10: Financing channels & 29 & 55 & 31 & 62 & 26 & 70 & 07 & 37 \\
\hline EPA11: Investment plan & 23 & 44 & 15 & 30 & 23 & 62 & 13 & 68 \\
\hline EPA12: Life cycle cost & 27 & 52 & 11 & 22 & 30 & 81 & 10 & 52 \\
\hline EPA13: Life cycle profit & 26 & 50 & 16 & 32 & 30 & 81 & 09 & 47 \\
\hline EPA14: Finance risk assessment & 28 & 54 & 16 & 32 & 18 & 49 & 06 & 31 \\
\hline EPA15: Return on investment (ROI) & 28 & 54 & 16 & 32 & 25 & 67 & 08 & 42 \\
\hline EPA16: Net present value (NPV) & 28 & 54 & 22 & 44 & 29 & 78 & 08 & 42 \\
\hline EPA17: Pay-back period & 29 & 56 & 22 & 44 & 31 & 83 & 08 & 42 \\
\hline EPA18: Internal rate of return (IRR) & 29 & 56 & 22 & 44 & 31 & 83 & 08 & 42 \\
\hline $\begin{array}{l}\text { SPA1: Influence to the local social } \\
\text { development }\end{array}$ & 05 & 10 & 42 & 84 & 07 & 19 & 10 & 52 \\
\hline $\begin{array}{l}\text { SPA2: Provision capacity of } \\
\text { employment }\end{array}$ & 06 & 11 & 06 & 12 & 07 & 19 & 08 & 42 \\
\hline $\begin{array}{l}\text { SPA3: Provision capacity of public } \\
\text { services }\end{array}$ & 06 & 11 & 26 & 52 & 13 & 08 & 05 & 26 \\
\hline $\begin{array}{l}\text { SPA4: Provision capacity of public } \\
\text { infrastructure facilities }\end{array}$ & 05 & 10 & 24 & 48 & 13 & 08 & 05 & 26 \\
\hline SPA5: Improvement to wellbeing & 05 & 10 & 07 & 14 & 03 & 08 & 03 & 16 \\
\hline SPA6: Safety standards & 00 & 00 & 06 & 12 & 00 & 00 & 07 & 37 \\
\hline $\begin{array}{l}\text { SPA7: Improvement to the public } \\
\text { health }\end{array}$ & 04 & 08 & 06 & 12 & 00 & 00 & 04 & 21 \\
\hline SPA8: Increase in consumption level & 03 & 06 & 06 & 12 & 17 & 46 & 08 & 42 \\
\hline $\begin{array}{l}\text { SPA9: Improvement to standards of } \\
\text { living }\end{array}$ & 03 & 06 & 07 & 14 & 16 & 43 & 06 & 31 \\
\hline $\begin{array}{l}\text { EnPA1: Eco-environmental sensitivity } \\
\text { of the project location }\end{array}$ & 01 & 02 & 15 & 30 & 12 & 32 & 04 & 21 \\
\hline EnPA2: Air impacts & 04 & 28 & 28 & 56 & 26 & 70 & 04 & 21 \\
\hline EnPA3: Water impacts & 04 & 08 & 32 & 64 & 23 & 62 & 07 & 37 \\
\hline EnPA4: Noise assessment & 05 & 10 & 26 & 52 & 23 & 62 & 05 & 26 \\
\hline EnPA5: Waste assessment & 00 & 00 & 28 & 56 & 23 & 62 & 09 & 47 \\
\hline $\begin{array}{l}\text { EnPA6: Environmental friendly } \\
\text { design }\end{array}$ & 00 & 00 & 17 & 34 & 26 & 70 & 00 & 00 \\
\hline $\begin{array}{l}\text { EnPA7: Energy consumption } \\
\text { performance }\end{array}$ & 03 & 06 & 14 & 28 & 20 & 50 & 07 & 37 \\
\hline
\end{tabular}


CSR is largely insufficient for making face the negative externalities generated by industrial production to be harmful the welfare of population; given that $\mathrm{SPA}_{5}$ "Improvement to wellbeing" is only $8 \%$ and note $\mathrm{SPA}_{6}$ "Safety standards" along with $\mathrm{SPA}_{7}$ "improvement to the public health" were recorded. For commercial project, the influence to the local social development is manifested on $\mathrm{SPA}_{6}$ "safety standards" and $\mathrm{SPA}_{8}$ "Increase in consumption level". However, the impact degree is still low, it is therefore necessary to make greater effort within the framework of social performance for the future project. It is right and normal when the government promotes the environment for social performance because this latter is part of the State sovereign function. It is not surprising when there is a local development impulsion. However, the conjugated efforts about $\mathrm{SPA}_{3}$ "provision capacity of employment" and $\mathrm{SPA}_{4}$ "provision capacity of public infrastructure facilities" remain insufficient for encouraging $\mathrm{SPA}_{6}$ "safety standards", $\mathrm{SPA}_{7}$ "improvement to the public health" and $\mathrm{SPA}_{8}$ "increase in consumption level". Therefore, the difference between the social strata does not stop to dramatize because the rich get richer and the poor get poorer.

\subsection{Environmental \& Social Attributes}

Environmental performance attributes (EnPAs) gather some indicators that measure the variation of environmental performance in respect of industrial projects as well as induced construction projects. Research works in this direction have been conducted [16] [21]. By analyzing surveyed the feasibility reports, a list of EnPAs were drawn up as shown in Table 1. A series of respective values of variation were combined during application of these attributes. Table 2 provides a statistical summary of the application EnPAs in four types of projects surveyed.

Table 2 also provides detailed information on the proportion of environmental destruction through the values of each attributes. It is found that three major projects (i.e. residential projects, industrial and trade) are among the destructive environmental factors. A great imbalance between EnPA $A_{1}$ recorded was "eco-environmental sensitivity of the project location" and EnPA ${ }_{2}$ "Air impacts", EnPA 3 "Water impacts" and EnPA ${ }_{4}$ "Noise assessment" for these three respective projects. This means that the contribution of economic growth generated by these three projects cannot cover the expenses necessary to repair environmental damage. Worse yet health disorders caused by EnPA 4 "noise assessment" and $\mathrm{EnPA}_{5}$ "waste assessment".

Generally, the pollution effect measure the environmental performance degradation including industrial waste that may affect the air and water. Moreover, previous studies have mentioned that China's environment suffered greatly by the implementation of many construction projects. Indeed, much remains to be done for the government to make up for current environmental problems. It must at all costs redouble efforts on EnPA 6 "Environmental friendly design" to restore the lost natural landscape and especially more effort to curb different types of pollution threaten human life. It can deduce that the negligence of study environmental impact of different construction project during the two last decades has led to the current state of environmental degradation in China (Table 2).

\section{Recommendations}

Promoting sustainable development requires stimulate economic growth which it has an induced effect on new expansion of social and environmental issues. Indeed, first of all, the study of socio-economic and environmental impact is irrefutable about industrial or construction projects. This study will discern the economics' advantages on one hand, and environmental disadvantages induced on the other hand [33]. Research focused on the project implementation such as CCTEC Co. Ltd. should emphasize more on methods that enables for improving the quality of economic performance, social and environmental for the future of the industry practice. This comes down to say that it is time to replace the traditional approach by a new approach which embraces the principles of sustainable development.

The mutation process towards sustainable development is a long and exacting task; indeed, the government cannot assume to itself the sustainable development principle implementation [34]. Subsequently, everyone's contribution including population and the private sector is undeniable.

\subsection{Government}

The government plays an utmost important role in promoting sustainable development. It encourages all in- 
come-generating activities that contribute not only to improving fiscal resources but also providing a new impetus to social development [34] [35]. The government fixes policies, laws and regulations which permit regulate the imbalance between economic, social and environmental interests [34]-[36]. Violation of laws and regulations requires the tax penalty payment by the infractions perpetrators. Thus, revenues from duties and taxes and fines will strengthen the state treasury to finance the activities to characters humanitarian.

\subsection{Clients}

At present, the project leaders must consider about the sustainable development prospects. Indeed, the team of research project must be composed of multidisciplinary researchers including engineers, economists, managers, sociologists, environmentalists etc. The involvement of these different researchers during the design phase of projects takes into account that the said project will be mainly focused on the wellbeing of population. For this purpose, a study is made for mitigating potential impacts on the environment including air impacts, water impacts, noise impacts and waste assessment. Thus, within the framework of the project viability improvement, the clients should not only focus on the economic performance study, but the study should be extended into the social and environmental fields. This implies collaboration with all stakeholders including Non-Governmental Organizations (NGOs) and civil society [35]. Their opinion should be incorporated in conducting project management.

\subsection{Contractors and Suppliers}

The traditional practice does not provide access to contractors and suppliers as being the best elements to consult during the phase of project design study. However, they have detailed information on methods enabling to reduce environmental influences generated by construction operation [37]. Given that they have enough experience as prime contractor of projects, they can choose the required materials quality or replacement materials in the context of projects sustainability [38]. This sustainability projects perspective produces a feedback on the capital goods quality or materials production to producing factory. Thus, the consideration of contractors and suppliers stakeholders unavoidable might influence on one hand CCTEC Co. Ltd. to proceed a new capital good design or materials production in accordance of requirements of sustainable development principle. On the other hand, they can work together with the company as a partner to find issues on waste generation, air and noise pollution and water pollution.

\section{Conclusion}

This paper decrypted economic interest provided by the existence of processing industries. The economic development resurgence is reflected partially in the social field. Indeed, the supply of capital goods and construction materials promotes the basic infrastructure development including the public sector, residential projects, industrial and commercial. However, the implementation of these four projects will not let the environment state remains intact. Analysis on production process practice and especially the followed of the use of products has enabled to set four types of attributes. Seventeen economical, nine social and seven environmental performance attributes were explored from 158 sold machinery. The result attained in the projects has made considerable impulsion on the economic aspect. The economic situation improvement has not significantly impact on everyone life, in contrast, the natural environment state has deteriorated further, which indicates that the distribution of wealth newly created is not fair. Individual factors derive considerable profits at the expense of the population victim of environmental pollution. The traditional approach is lapsed; indeed, it is no longer question to take into account the traditional approach in studies of project design. The use of the new approach is strongly recommended from design in passing by operation until the project is to its terms. In this sense, work together between all stakeholders is indispensable including government, clients, NGOs and contractors and suppliers [39] [40].

\section{References}

[1] Lappe, M. and Spang, K. (2014) Investments in Project Management Are Profitable: A Case Study-Based Analysis of the Relationship between the Costs and Benefits of Project Management. International Journal of Project Management, 32, 603-612.

[2] Xue, X.L., Shen, Q.P., Tan, Y.T., Zhang, Y. and Fan, H.Q. (2011) Comparing the Value of Information Sharing under 
Different Inventory Policies in Construction Supply Chain. International Journal of Project Management, 29, 867-876. http://dx.doi.org/10.1016/j.ijproman.2011.04.003

[3] Dong, W. (2012) The Role of Expenditure Switching in the Global Imbalance Adjustment. Journal of International Economics, 86, 237-251. http://dx.doi.org/10.1016/j.jinteco.2011.08.017

[4] Chen, Y.M. and Zhang, T.L. (2011) Equilibrium Price Dispersion with Heterogeneous Searchers. International Journal of Industrial Organization, 29, 645-654. http://dx.doi.org/10.1016/j.ijindorg.2011.03.007

[5] Barattier, A. (2014) Comparative Advantage, Service Trade, and Global Imbalances. Journal of International Economics, 92, 1-13. http://dx.doi.org/10.1016/j.jinteco.2013.11.004

[6] Hueting, R. (2009) Why Environmental Sustainability Can Most Probably Not Be Attained with Growing Production. Journal of Cleaner Production, In Press.

[7] Herman, E., Georgescu, M.A. and Georgescu, A. (2012) Ethics between Theory and Practice-Social Responsibility in the Romanian Business Environment. Procedia Social and Behavioral Sciences, 58, 703-713.

[8] Basu, R. (2014) Managing Quality in Projects: An Empirical Study. International Journal of Project Management, 32, 178-187. http://dx.doi.org/10.1016/j.ijproman.2013.02.003

[9] Sun, J. and Zhang, P.L. (2011) Owner Organization Design for Mega Industrial Construction Projects. International Journal of Project Management, 29, 828-833. http://dx.doi.org/10.1016/j.ijproman.2011.04.005

[10] Chen, Y.-S., Lin, M.-J. J. and Chang, C.-H. (2009) The Positive Effects of Relationship Learning and Absorptive Capacity on Innovation Performance and Competitive Advantage in Industrial Markets. Industrial Marketing Management, 38, 152-158. http://dx.doi.org/10.1016/j.indmarman.2008.12.003

[11] Guest, R.S. and McDonald, I.M. (2007) Global GDP Shares in the 21st Century-An Equilibrium Approach. Economic Modelling, 24, 859-877. http://dx.doi.org/10.1016/j.econmod.2007.03.001

[12] Ruggieri, L., Cadena, E., Martinez-Blanco, J., Gasol, C.M., Rieradevall, J., Gabarrell, X., et al. (2009) Recovery of Organic Wastes in the Spanish Wine Industry. Technical, Economic and Environmental Analyses of the Composting Process. Journal of Cleaner Production, 17, 830-838. http://dx.doi.org/10.1016/j.jclepro.2008.12.005

[13] Lappe, M. and Spang, K. (2014) Investments in Project Management Are Profitable: A Case Study-Based Analysis of the Relationship between the Costs and Benefits of Project Management. International Journal of Project Management, 32, 603-612. http://dx.doi.org/10.1016/j.ijproman.2013.10.005

[14] Jung, H.S., Kim, K.H. and Lee, C.H. (In Press) Influences of Perceived Product Innovation upon Usage Behavior for MMORPG: 2014, Product Capability, Technology Capability, and User Centered Design. Journal of Business Research.

[15] Felício, J.A., Gonçalves, H.M., da Conceição Gonçalves, V. (2013) Social Value and Organizational Performance in Non-Profit Social Organizations: Social Entrepreneurship, Leadership, and Socioeconomic Context Effects. Journal of Business Research, 66, 2139-2146. http://dx.doi.org/10.1016/j.jbusres.2013.02.040

[16] Boggia, A. and Cortina, C. (2010) Measuring Sustainable Development Using a Multi-Criteria Model: A Case Study. Journal of Environmental Management, 91, 2301-2306. http://dx.doi.org/10.1016/j.jenvman.2010.06.009

[17] Halawa, W.S., Abdelalim, A.M.K. and Abd Elrashed, I. (2013) Financial Evaluation Program for Construction Projects at the Pre-Investment Phase in Developing Countries: A Case Study. International Journal of Project Management, 31, 912-923. http://dx.doi.org/10.1016/j.ijproman.2012.11.001

[18] Wang, J., Xu, Y.J. and Li, Z. (2009) Research on Project Selection System of Pre-Evaluation of Engineering Design Project Bidding. International Journal of Project Management, 27, 584-599. http://dx.doi.org/10.1016/j.ijproman.2008.10.003

[19] Ramasamy, B., Yeung, M.C.H. and Chen, J.S. (2013) Selling to the Urban Chinese in East Asia: Do CSR and Value Orientation Matter? Journal of Business Research, 66, 2485-2491.

[20] Scott-Young, C. and Samson, D. (2008) Project Success and Project Team Management: Evidence from Capital Projects in the Process Industries. Journal of Operations Management, 26, 749-766. http://dx.doi.org/10.1016/j.jom.2007.10.006

[21] Wang, D.T. and Chen, W.Y. (2014) Foreign Direct Investment, Institutional Development, and Environmental Externalities: Evidence from China. Journal of Environmental Management, 135, 81-90. http://dx.doi.org/10.1016/i.jenvman.2014.01.013

[22] Parast, M.M. and Adams, S.G. (2012) Corporate Social Responsibility, Benchmarking, and Organizational Performance in the Petroleum Industry: A Quality Management Perspective. International Journal of Production Economics, 139, 447-458.

[23] Haapio, A. and Viitaniemi, P. (2008) A Critical Review of Building Environmental Assessment Tools. Environmental Impact Assessment Review, 28, 469-482. http://dx.doi.org/10.1016/j.eiar.2008.01.002 
[24] Tam, W.Y.V. (2008) On the Effectiveness of Implementing a Waste-Management-Plan Method in Construction. Waste Management, 28, 1072-1080. http://dx.doi.org/10.1016/j.wasman.2007.04.007

[25] Adams, L., Régibeau, P. and Rockett, K. (2014) Incentives to Create Jobs: Regional Subsidies, National Trade Policy and Foreign Direct Investment. Journal of Public Economics, 111, 102-119.

http://dx.doi.org/10.1016/j.jpubeco.2013.12.015

[26] Serra, C.E.M. and Kunc, M. (2014) Benefits Realisation Management and Its Influence on Project Success and on the Execution of Business Strategies. International Journal of Project Management, 1-14.

[27] Llanes, G. and de Elejalde, R. (2013) Industry Equilibrium with Open-Source and Proprietary Firms. International Journal of Industrial Organization, 31, 36-49.

[28] Wang, W. (2013) An Empirical Study of the Relationship between the US FDI Inflows and China-US Bilateral Trade Imbalances: Based on Vertical Specialization. Vertical Specialization and Trade Surplus in China, 79-94. http://www.sciencedirect.com/science/article/pii/B9780857094469500071

[29] Bouton, L., Gassner, M. and Verardi, V. (2008) Redistributing Income under Fiscal Vertical Imbalance. European Journal of Political Economy, 24, 317-328. http://dx.doi.org/10.1016/j.ejpoleco.2008.01.003

[30] Bonatti, L. and Fracasso, A. (2013) Hoarding of International Reserves in China: Mercantilism, Domestic Consumption and US Monetary Policy. Journal of International Money and Finance, 32, 1044-1078. http://dx.doi.org/10.1016/j.jimonfin.2012.08.007

[31] Lombardo, G. and Ravenna, F. (2014) Openness and Optimal Monetary Policy. Journal of International Economics, 93, 1-20. http://dx.doi.org/10.1016/j.jinteco.2014.01.011

[32] Bhattarai, K. and Mallick, S. (2013) Impact of China's Currency Valuation and Labour Cost on the US in a Trade and Exchange Rate Model. The North American Journal of Economics and Finance, 25, 40-59. http://dx.doi.org/10.1016/j.najef.2013.03.001

[33] Mir, F.A. and Pinnington, A.H. (2014) Exploring the Value of Project Management: Linking Project Management Performance and Project Success. International Journal of Project Management, 32, 202-217.

[34] Ramamurti, R. (2003) Can Governments Make Credible Promises? Insights from Infrastructure Projects in Emerging Economies. Journal of International Management, 9, 253-269. http://dx.doi.org/10.1016/S1075-4253(03)00036-X

[35] Davis, K. (2014) Different Stakeholder Groups and Their Perceptions of Project Success. International Journal of Project Management, 32, 189-201. http://dx.doi.org/10.1016/j.ijproman.2013.02.006

[36] Lee, S.H., Peng, M.W. and Song, S. (2013) Governments, Entrepreneurs, and Positive Externalities: A Real Options Perspective. European Management Journal, 31, 333-347. http://dx.doi.org/10.1016/j.emj.2013.01.006

[37] Larsen, T.J. and Olaisen, J. (2013) Innovating Strategically in Information and Knowledge Management: Applications of Organizational Behavior Theory. International Journal of Information Management, 33, 764-774. http://dx.doi.org/10.1016/j.ijinfomgt.2013.05.003

[38] Smyth, H. and Lecoeuvre, L. (2014) Differences in Decision-Making Criteria towards the Return on Marketing Investment: A Project Business Perspective. International Journal of Project Management, in Press. http://dx.doi.org/10.1016/j.ijproman.2014.03.005

[39] Shen, L.Y., Platten, A. and Deng, X.P. (2006) Role of Public Private Partnerships to Manage Risks in Public Sector Projects in Hong Kong. International Journal of Project Management, 24, 587-594. http://dx.doi.org/10.1016/j.ijproman.2006.07.006

[40] El-Gohary, N.M., Osman, H. and El-Diraby, T.E. (2006) Stakeholder Management for Public Private Partnerships. International Journal of Project Management, 24, 595-604. http://dx.doi.org/10.1016/j.ijproman.2006.07.009 
Scientific Research Publishing (SCIRP) is one of the largest Open Access journal publishers. It is currently publishing more than 200 open access, online, peer-reviewed journals covering a wide range of academic disciplines. SCIRP serves the worldwide academic communities and contributes to the progress and application of science with its publication.

Other selected journals from SCIRP are listed as below. Submit your manuscript to us via either submit@scirp.org or Online Submission Portal.
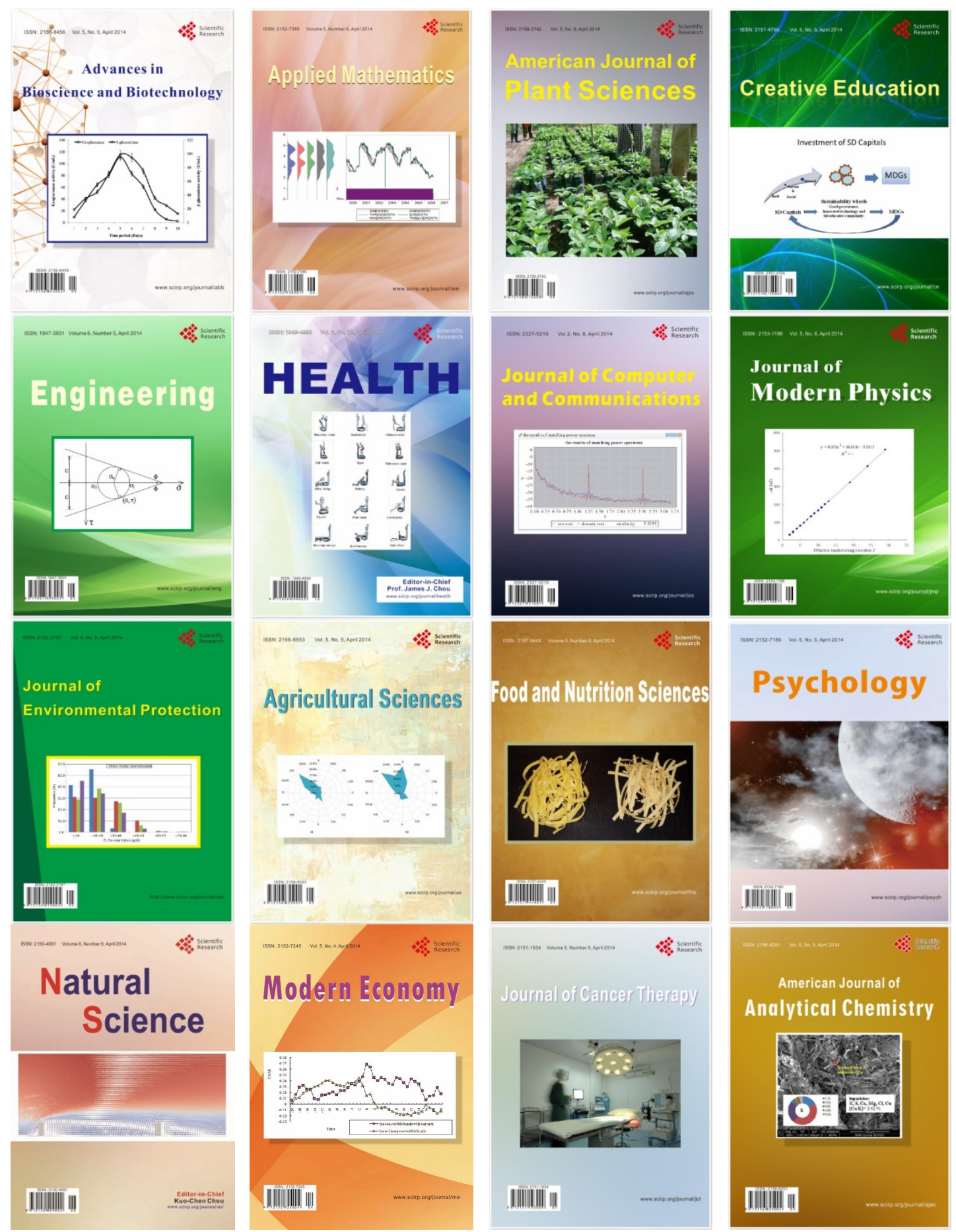